\title{
An Analysis of the Content, Policies and Assessment of ICT Curricula in the Final Years of Secondary Schooling in Australia and Vietnam: A Comparative Educational Study
}

\author{
Thang Manh Tran and Dorian Stoilescu \\ Centre for Educational Research, School of Education, \\ Western Sydney University, Penrith, New South Wales, Australia \\ tmthang@yenbai.edu.vn dstoilescu@yahoo.ca
}

\begin{abstract}
This paper explores and analyses similarities and differences in ICT curricula, policies, and assessment between the Vietnamese and Australian educational systems for the final years of secondary educational level. It was found that while having a common core set of tendencies, the Australian ICT curricula, policies, and assessments differ markedly from the Vietnamese counterparts. These differences can be explained by economic and cultural factors, national-wide educational trends, ICT strategies, and their degrees of implementation in schools. We found that limited constructivist implementations are used in ICT curricula in both countries, as Australian education has high expectations in national evaluations with an emphasis on standardized tests and Vietnamese education is still entrapped in prescriptive lessons of traditional pedagogy, emphasizing transmission model of information. We found that lack of opportunities in teacher professional development in ICT training is common for both countries. While the Australian educational system still struggles, especially in providing opportunities for learning theoretical and programming aspects, multiple challenging aspects were found in the ICT content and policies of the Vietnamese educational system that call for immediate change and improvement. In this sense, Vietnamese administrators are recommended to extensively follow up their educational strategies and policies, in order to make sure that their reforms are adequately implemented in schools. In order to bridge the gap and implement adequate ICT curricula, rigorous professional training in ICT teaching is essential for both Australian and Vietnamese teachers.
\end{abstract}

Keywords: ICT education, comparative studies in ICT education, ICT curriculum, ICT policies, ICT assessment.

Material published as part of this publication, either on-line or in print, is copyrighted by the Informing Science Institute. Permission to make digital or paper copy of part or all of these works for personal or classroom use is granted without fee provided that the copies are not made or distributed for profit or commercial advantage AND that copies 1) bear this notice in full and 2) give the full citation on the first page. It is permissible to abstract these works so long as credit is given. To copy in all other cases or to republish or to post on a server or to redistribute to lists requires specific permission and payment of a fee. Contact Publisher@InformingScience.org to request redistribution permission.

\section{Introduction}

It is fair to say that the 21 st century has ushered in a time of universal acceptance of the essential role of information and communication technology (ICT) of economic, social, and educational changes (Kozma, 2008; Willinsky, 2014). As a result, ICT has been accepted as a key aspect of education, as 
radically changing and reforming all aspects of education (Scardamalia \& Bereiter, 2014; Stoilescu, 2005, 2009). Globally, ICT is now an essential aspect of national curriculums. One of the core aspects is software programming, which requires extended literacy and numeracy skills (Higgins, 2003). Furthermore, another important aspect of ICT curriculum is being able to understand various aspects of practical and theoretical ICT devices, tools, software and skills, by enabling students to make valuable contributions in various areas of learning (Tyner, 2014). In consequence, ICT education has become a fundamental component of general education and provides students with opportunities to develop widely valued skills and abilities such as literacy and numeracy around computing and communications devices, software, applications, and systems.

Australia has taken advantage of implementing a great number of advanced ICT policies in its curriculum (Markauskaite, 2005). As such, it has accrued an established education system able to participate in the global shift, from material production to knowledge economy, where intellectual resources are the basis for economic growth. In this sense, all state, territory, and federal Australian governments support major programs to increase the use of ICT in schools (Australian Government, 2013; Convery, 2009). The major national initiative called Digital Education Revolution (DER) (2008) was successful implemented in the last years. As a result, for educational purposes schools can offer one computer per child during classes.

Similarly, in 2009, the Vietnamese Ministry of Education and Training (VMOET) implemented a national strategy called the National Plan for ICT in Education, when the government recommended measures such as innovative curricula and methodologies for modular knowledge, updated new technology, and the deployment of teacher training (VMOET, 2008). For both countries the ICT curriculum has become a major subject and is being taught in high schools. However, a great number of ICT teachers in Australia and Vietnam have not yet met the requirements of adequate teaching quality (Australian Government, 2013; Bertram \& Waldrip, 2013; Pham 2012; Vietnamese Assembly 2014; Vu 2008).

This article aims to contribute in analyzing, comparing, and understanding of content, knowledge, policies, and skills emphasized by the ICT curricula and assessments, in the final years of secondary school in both countries, by using comparative education methodologies. As the Australian education system has specific rules for education for each state, for this paper only the state of New South Wales (NSW) will be considered to represent Australian education. In contrast, in Vietnam, the national educational system has a fully synchronized access between local schools and a centered educational organization, and therefore we will consider this discussion at national level. The three main research questions of this article are the following: 1) What does the analysis of the official content, policies, and assessment of the ICT Curricula reveal about Australia and Vietnam? 2) What are the similarities and differences? 3) What are the implications?

This research has several purposes. First, it analyses the content of the curriculum in both countries and shows the difference that these countries have in defining ICT curriculum. Second, it exhibits ways in which the officials in both countries attempt to provide adequate resources, knowledge, and skills in ICT curriculum. Third, it endeavors to determine more precisely the distance between the current ICT requirements for ICT high school curriculum content and assessment and the actual level of performance by teaching staff. Fourth, it aims to discuss leadership challenges in developing adequate ICT teachers. As such, it is hoped that this project in comparative education will contribute to the understanding of requirements of ICT content and policies in secondary schools. 


\section{A Review of Literature in ICT Teaching and Learning and Comparative Education}

\section{ICT Education becomes a Global Approach}

ICT education in schools has been affected by the rapid development of ICT devices, knowledge, and skills among individuals (Kozma, 2003, 2011; Livingstone, 2004). Development of the ICT curriculum offers potential and abilities to improve teaching and learning activities (Livingstone, 2012). The emergence of the various technologies and system applications available in ICT has had a profound impact on societies, disrupting the ways people access, process, save, and spread information within organizations across the world (Ubulom, Enyekit, \& Onuekwa, 2011). This revolution is affecting the nature of learning, the manufacture of knowledge, and the transformation of the world in surprising ways (Scardamalia \& Bereiter, 2014), with its influence becoming increasingly pronounced on a global scale (Kozma, 2003; Miller \& Akume, 2009). Its impact is rapidly being felt everywhere, with more and more necessary ICT products coming into existence (Kozma, 2003). Thus, ICT education includes more sophisticated higher-order skills and cognitive abilities (Hadjerrouit, 2009). As such, one of the goals of teaching ICT in schools is to achieve the objective of training students who will become ICT experts in the future and to improve the socio-economic status, in order to play a role in globalization process (United Nations Educational, Scientific and Cultural Organization [UNESCO], 2004).

Globalization of the ICT education was emphasized in many studies (Kozma, 2011; UNESCO, 2004). The important emphasis on developing ICT infrastructure might look unclear as there are already many policies in place in every country; yet there are rarely enough resources to cover the ICT required infrastructure (UNESCO, 2004). While some developed states have a well implemented ICT infrastructure, other developing states do not have a national infrastructure or are struggling to build a new one (UNESCO, 2004). Additionally, the problem extends to having adequately prepared ICT teachers. For instance, in these reviews it was found that Australia is considered among the countries with a well-developed ICT infrastructure, while Vietnam is mentioned as a developing country trying to implement the ICT infrastructure. Discussing the cultural aspects of ICT education in Vietnam, Peeraer and Tran (2010) recommended that constructivist aspects and a student-centered approach need to be implemented in classrooms. In Australia, while there is a lot of emphasis on preparing teachers to use digital resources, in fact there is a lack of effective pedagogical projects that train educators to use and design ICT tools (Ainley, Banks \& Fleming, 2002). In addition, although the educators are aware of the huge gap between the potential of technology and its actual effectiveness, in fact, this barrier proved very difficult to break, as it remains a systemic one and an international one (Ainley et al., 2002; Cuban, 2009).

Sansanwal (2009) reports that teaching ICT in schools focuses on imparting information which is beyond the sole objective of teaching. However, limited research work is available nowadays due to complex requests and the fast changing pace of technology (Kozma, 2011; Markauskaite 2007). According to Rautopuro, Pöntinen, and Kukkonen (2006), ICT functions in school education in three respects. Firstly, it is used as a kind of teaching and learning facility, making use of databases in subject areas such as mathematics or science. Secondly, its many learning materials enable it to work as a beneficial learning environment. Thirdly, it is considered as a subject in itself, in which its knowledge, concepts, skills, and processes can be learnt. Though there are varying definitions of ICT, many researchers believe that it is nonetheless quite a new field, different from mathematics, engineering, and science in its conception (Hadjerrouit, 2009; Tedre, 2007; Whitaker, 2007). 


\section{Standards and Content of ICT Curriculum and Assessment}

The content of ICT curriculum has evolved in time by allowing diverse paths for effective teaching and learning, as well updating the subject matter, themes, relevant skills, teachers and students' expectations, learning and pedagogic strategies, and assessment procedures. Farrell et al. (2007) point out that ICT teaching and learning in secondary schools face many difficulties in the following aspects:

- Infrastructure: One of the serious problems in the teaching and learning of ICT that schools face is insufficient infrastructure. For example, the teaching of some programs and manipulation of some software applications are difficult due to a lack of computers for practical lessons and didactic materials that can help students learn ICT;

- ICT curricula: The development of curricula for the teaching of ICT as a subject is still at an early stage and has not been clearly identified in response to a programme and time allocated for its teaching. Furthermore, there is a reported a lack of textbooks and reference books available for teachers and students;

- Teacher training: Most of those teaching ICT still lack the benefits of a well-structured training programme for ICT pedagogy;

- Motivation: Most students do not recognize the importance of ICT learning in schools;

- Teaching approach: ICT is being taught using traditional teaching methods which need to integrate new ICT pedagogy; and

- ICT Finance: The financing is essential for the sustainable teaching and learning of ICT is lacking. Unfortunately, the process of financing is difficult, as a great financial commitment is required to keep pace with the latest advancements in ICT.

In a comparative study of the quality of ICT teachers, Hadjerrouit (2009) gave evidence that there are six basic stages for facilitating teaching and learning processes: planning, design, instruction, assessment, evaluation, and feedback. In the case of ICT curriculum, at each stage Hadjerrouit found different difficulties such as lack of teachers' training, lack of study material, lack of computing resources, and lack of skills and pedagogical knowledge. It is widely acknowledged that student achievement is affected not only by officially prescribed curricula, but also by the way examinations are designed. For instance, according to Leung (2001), East Asian education systems are characterized by highly competitive examinations. Teachers and parents attach great importance to education, and there are high expectations for their students and children to succeed academically. Academic achievement has been considered a means of bringing honor to one's family. This high expectation to succeed provides another important source of motivation for student learning. In addition, the difference in social and economic status between the academically high qualified and low qualified is much greater in East Asia than in the West. This sends a message to students about the importance of academic achievement and constitutes another source of motivation for student learning.

Comparing the results of assessments is not always an easy approach. For instance, Jerrim (2015) indicates that the apparent superior performance of students in standard-based tests from some East Asian countries might be related to the form and content of tests. He shows that Western students performed better than their Asian counterparts in aspects such as using visual and graphical representations and solving open-ended problems. In addition, he suggests that the use of hands-on experience does not always guarantee students' conceptual understanding and high performance in paper-pen examinations, in which more efficient and generalized solution strategies might be needed. As such, an adequate way of designing assessments is needed, especially for the relative new ICT curriculum. In this sense, Quellmalz and Kozma (2003) designed a Coordinated 
ICT Assessment Framework, in order to test how student solve complex, significant, and applied problems.

\section{The Relationship between Teaching, Learning and Assessment in Comparative Education}

The recent surge of studies in comparative education (Sellar \& Lingard, 2013) might be explained through internationalization of educational policies, leading to a diffusion of global patterns and flows of knowledge that are assumed to be applicable in various places. It is important to emphasize that international standards and indicators are not created spontaneously (Nóvoa \& YarivMashal, 2007). In this sense, Cowen (2009) points out that "we have 'comparative educations' because what we call comparative education, in its growth, in its shape-shifting, is itself part of international, political, economic, cultural and educational relations" (p. 1289). Therefore, comparative education becomes more important because it is used in the development of educational understanding and the creation of new education programs and frameworks (Sellar \& Lingard, 2013). An important aspect of comparative education is contextualization. A nation's education system cannot be viewed in a vacuum, as social, political, and economic pressures are all involved in shaping education systems and determining outcomes. Nations with a strong national tradition of education can have better outcomes with less funding than nations that have not historically valued education (Hans, 2013).

The importance of providing an adequate framework for ICT education to compare teaching, learning, and assessment from different countries has become vital. One of the most prestigious institutes engaged with large comparative studies in ICT education is the International Association for the Evaluation of Education Achievement (IEA). This organization was established in 1959 and is a cooperative network of research centers that conduct international comparative studies in schools and aid the research community in developing international tests and statistical analyses (Husén, 1967). Today, the membership of IEA consists of institutions from more than 63 counties and 14 benchmarking entities (regional jurisdictions of countries such as states) to enable international comparisons among the key aspects in curriculum, instruction, and resources that result in higher levels of student achievement (Mullis, Martin, Ruddock, O'Sullivan, \& Preuschoff, 2009). One of the comparative educational areas of the IEA is the ICT curriculum. For instance, in 1997 the IEA decided to conduct the Second Information Technology in Education Study (SITES). SITES focused on assessing the current situation of ICT in education against the presence of pedagogical practices considered important for ensuring that citizens acquired the skills necessary to function well in the Information Society. Many of IEA's studies, especially SITES, tested a considerable number of variables related to ICT achievement, thereby providing a basis for this study.

In addition to the IEA studies, there have been a great number of comparative studies in ICT education that studied the development of ICT in international contexts. For instance, The Organization for Economic Cooperation and Development (OECD) launched in 2000 a major study on the importance of ICT in education. The study focused on ICT's impact on educational innovation and reform, the role of the teacher, and the issue of access to ICT. The OECD (2005) study also emphasizes the economic importance and impact of ICT in developed countries and points out the need of these countries to develop a workforce with skills to use ICT to increase productivity, as well as the need for young people to develop ICT skills to prepare for adult life.

What this study refers to as contextual factors need to be set out here in general terms, because the context of the syllabus and educational philosophy that underlies ICT teaching and learning in each country will influence the gathering of information and the interpretation of that information. Adamson (2012) shows that when it comes to the question of a comparison between the two educational systems, it is important to clarify the following areas of potential contrast that 
may apply: 1) Intended curriculum versus the actual practice of the curriculum; 2) The application of pedagogical theory in each country in relation to dominant ideological concerns; 3) The value of general ICT education versus occupational expectations. Kalenda and Schwartzhoff (2015) discuss the application of "cultural sociology" to the study of education. Culture is not often a meaningful part of analytical studies on education, and existing studies in their view are "mostly based on utilitarian and materialistically oriented approaches" (p. 1).

\section{Summary of Comparative Education Perspectives in ICT Education}

In summary, the literature reviewed in this section suggests the need to use adequate methods that are able to explore content and policies in curricula and assessment practices in authentic settings cross-culturally. This review has provided a background and framework for designing a comparative study on ICT curricula and assessment between Australian and Vietnamese secondary schools. The comparison between ICT education in Vietnam and Australia does have particular characteristics that will guide research into specific aspects that will offer valid conclusions regarding similarities and differences between the two systems.

\section{Methodology}

This study deploys qualitative research methods that involve an interpretive, naturalistic approach to its subject matter (Denzin \& Lincoln, 2009), in order to develop a kind of scientific research. These approaches aim to find answers to questions, use a system of predefined procedures to answer them, gather evidence, produce findings that are not predefined, and produce findings that can be applied immediately, beyond the boundary of the present research study (Mack, Woodsong, MacQueen, Guest, \& Namey, 2005). As such, it is important to establish a theoretical paradigm for this research. Comparing Vietnamese and Australian education might be seen as adjusting Vygotsky and the social construction of knowledge to fit into a Marxist perspective and ultimately be reconciled with the post-structural theories. These very different approaches cannot be easily reconciled (Hruby, 2001). This is the kind of over-simplification that we need in this research, where constructivism is often discussed in Vietnam and Australia and not only has its particular local connotations but actually means different things in each context. In considering constructivism in education in Vietnam, it is important to keep in mind that in Vietnam, as an Asian country with a socialist regime, the governing party is the Communist Party and there is a dominant role of State and collective property. In Western societies, however, due to a more capitalist and individualist orientation, the history of the introduction of Vygotsky's thinking in a climate of Postmodernism and Post-structuralism have meant that constructivism has acquired a different image.

We base our analysis on Kozma's (2011) approach by using his four-dimension framework of ICT education: a) infrastructure development, b) leadership, c) teacher training and technical support, and d) curriculum development. This framework developed by Kozma (2011) will be used to compare the operations of ICT content and policy in Australia and Vietnam. The three main research questions are the following: 1) What does the analysis of the official content and assessment of the ICT curricula reveal about Australia and Vietnam? 2) What are the similarities and differences? 3) What are the implications? First, we analyzed the way the ICT curricula are defined in both countries. We tried to see similarities and differences in the content of the ICT curriculum. Likewise, we analyzed the major areas of study, the time allocated, the content, and the activities requested to be performed. We attempted to see the way constructivism was used in the ICT documents in both countries. For textbooks, we noticed that in Vietnam they were already prescribed at the national level, while in Australia these resources were left to ICT teachers from each school. In the end, for the third research question, we discuss the implications that we 
learn from this research. These categories obtained from analysis were interpreted in broad cultural contexts so that we could obtain adequate significance.

The main method used in this paper is a thematic analysis of ICT documents and policies (Crabtree \& Miller, 1999; Daly, Kellehear, \& Gliksman, 1997) of the important documents in the ICT education in Vietnam and Australia. The important documents associated with government ICT policies and intended curriculum addressed in international comparative research include government guidelines on teaching, learning, curriculum content, and assessment related to teaching programs that look to produce specific ICT outcomes. By using thematic analysis, explicit descriptions of Australian and Vietnamese ICT curriculums can be analyzed. This analysis is focused on the secondary school ICT curriculum, learning, and assessment guidelines from the final years (Years 11 and 12, which in Australia is called Stage 6).

By careful interpreting and reading the document, this approach identifies aspects and patterns of emerging tendencies that described the content and assignments of ICT curriculum. It is based on a priori set of codes, approach outlined by Crabtree and Miller (1999). This set of codes was created before commencing an in-depth analysis of the data, by using Kozma's (2011) theoretical framework and doing a preliminary scanning of the text. As for the ICT curricula we added a quantitative approach, in order to reveal the importance that each area has in overall ICT curriculum in each country.

There is extensive literature to support the coding and categorizing of qualitative data (Bogdan \& Biklen, 2007). However, a number of authors have challenged the singular focus on these procedures. For instance, Maxwell (2012) agrees with the value of coding and categorization for identifying general themes and theoretical concepts to gain general understandings and to test ideas, but states that an exclusive focus on coding runs the risk of neglecting contextual relationships among the data, relationships based on contiguity rather than similarity. When research finds similarities and differences across settings, coding helps address these questions, but if the research asks about how the ways and factors in a specific area are connected, contextualizing analysis is required. In our analysis, we used a similar approach from the IEA and Kozma (2011), one of the most important researchers affiliated with IEA. The IEA studies normally use a coding system to analyze and report data about policy and curriculum documents. In our research, we used the following major stages.

The document analysis encompasses two main components: first, a highly detailed description of curriculum guidelines, syllabus, assessment, and textbooks; second, a critical evaluation of the curriculum rationale and the limitations and strengths of the curriculum content and its implications. The process of document analysis consisted of three steps. The first step was to select appropriate documents. The Vietnamese ICT policies, curricula, and textbooks are highly controlled and issued by the Vietnamese Ministry of Education and Training. For Australia, the most difficult aspect of document analyses was choosing the most influential documents that represented authentic ICT curricula and assessment practices, as the country has different organizations that have various roles and play by different rules (Prestridge, 2012). In contrast to Vietnam, curriculum implementation in Australia is largely a matter for individual schools, even though mandated state documents are required. The second step was to categorize each document into key segments on which more detailed analysis could be completed. The last step was to compare key differences and similarities between the documents and discuss the rationale underlying the identified similarities and differences. Thematic analysis explores themes viewed as being important to the description of the phenomenon (Daly et al., 1997). 


\section{Main Findings about the Secondary ICT Curricula, Policies and Assessment in Australia and Vietnam}

We refer our findings to the four-dimension framework of Kozma (2011). This first dimension from findings presents an overview of implementing ICT infrastructure in both countries. In Australia, the major national initiative, called the Digital Education Revolution (DER) (2008), offers us evidence of major reform being implemented at national level. More exact, DER delivered an efficient plan for access to the ICT infrastructure, so that every school has access to a wide use of digital teaching and learning resources. In addition, DER provided an adequate framework of using tools for processing information and a foundation for knowledge, communication, and collaboration in all areas of curriculum. In addition, ICT leadership ensures a coordinated plan to provide schools with infrastructure, learning resources, and teacher capacity to address 21 st century educational challenges. ICT professional development makes sure that teachers have the skills and tools to design and deliver knowledge and skills that meet student needs and mobilize the benefits and resources of the DER. Further, learning resources are mandated to stimulate and assist student learning outcomes, including collaborative and interactive activity guides, and instructional and reference materials. Similar to Australia, the Vietnamese government invests in ICT infrastructure for high schools (VMOET, 2008). There are some differences though. For instance, the plan is not made explicit as the DER was made. In addition, there is no one-to-one ratio student per computer, as in Australia. Instead, students work in groups in computer practice rooms, normally two or three students per computer.

The second dimension refers to leadership in both countries. We found that in both countries, the administrators strongly encourage teachers to extensively use ICT resources. However, we noticed some differences. One of the main differences is that the Vietnamese administrators do not follow up the way the ICT implementations are approached. Moreover, the ICT resources were not efficiently used for learning and teaching. Instead, Vietnamese ICT teachers and their students were requested to regularly use textbooks that are often obsolete. As a result, because of the heavy demand of using textbooks by the national educational system, the ICT teachers do not use digital resources. In contrast, in Australia administrators are regularly requested to follow up the use of ICT resources and find ways of pedagogically using ICT in schools. Consequently, learning and teaching were drastically changed by the use of ICT resources, as most of the disciplines actively use digital resources for learning and teaching purposes.

The third dimension refers to teacher professional training. We found that professional learning remains a difficult issue in both countries. For instance, in Australia, the final report from the DER (Australian Government, 2013) confirmed that "achieving 1:1 access and reliable infrastructure were a necessary pre-requisite to engaging teachers in the process of changing practice and actively seeking opportunities for professional learning" (p. 40). However, the teaching professional development was not properly addressed as the report explicitly acknowledges a reduced number of teaching professional opportunities in ICT education. The situation was found more severe in Vietnam, where VMOET (2008) confirmed a severe lack of ICT resources and a lack of adequate teacher professional opportunities. As such, it was recommended a more rigorous implementation of ICT education:

The curriculum must clearly reflect the general education goals and objectives of each level of education, discipline; provisions required to be achieved in the quality and capacity of students for each level of education, evaluation educational outcomes for subjects in each grade. (Vietnamese Assembly, 2014, p. 3)

The fourth dimension refers to the use of ICT curriculum and, as expected, it has the largest portion in our study. The importance of ICT curriculum was heavily emphasized by the Vietnamese government in numerous documents. Nonetheless, these aspects were not critically and practical- 
ly implemented. For instance, it was noticed that VMOET (2008) does not articulate specific educational objectives for ICT in education and does not have a practical procedure in place for evaluating content delivery. For example, the government requires that by 2010, 100 per cent of high school students are to be studying ICT, and by 2020 all school students are to be doing so. Further, by 2020, all students at every level are to be studying the application of ICT. Yet, the differences and similarities between students learning ICT and students learning the applications of ICT were not clarified. In addition, there was a delay of reporting the results of ICT reforms by the government. More exactly, the National Plan for ICT in Education was issued in 2009, when the government recommended measures such as innovative curricula and methodologies for modular knowledge, updated new technology, and the deployment of teacher training. Nevertheless, five years later, the Vietnamese Government has not reported on its progress in implementing ICT education in schools. The objectives for ICT education in Vietnam may be well-intended, but are lacking clear definition in important ways.

Overall, although the two systems have different emphases, they do share multiple common characteristics. Analysis shows that both systems divide curriculum objectives into formative and non-formative domains. Formally, both systems accept that ICT education should aim to develop student capacities of comprehension, application of formulas and principles, analysis of problems and synthesis of conclusions, and thoughtful evaluation. Both systems aim to develop students' basic ICT competence, though there are differences in the relative emphasis placed on knowledge and skills respectively. Certainly both systems distinguish the importance of problem solving in ICT learning. This is recognized as well in non-formal aspects of education. For instance, ICT is acknowledged as being part of day-to-day life, as the process of instruction might take place outside schools and universities.

As with other countries, the national policy on ICT in Australia and Vietnam sees ICT teaching and learning as directly affecting national development. Yet, in many significant ways, there are differences in the implementation of ICT curriculum between the two countries. In Australia, what the government actually achieves is transparently recorded in public Annual Reports. In Vietnam, there are many gaps in the record of the implementation of ICT educational policies. So far, no national report has surfaced to demonstrate progress, and there are still no specific standards for evaluating ICT teaching and learning. Though the economic, social, and political circumstances of the two countries differ, certain Australian educational procedures in relation to ICT could serve as useful models for the Vietnamese Government.

Vietnamese syllabus documents describe the objectives of ICT teaching in secondary schools in different ways. These objectives, ordered according to their importance, indicate that cognitive aspects of learning are a priority in the current Vietnamese ICT curriculum, which focuses not only on fundamental knowledge and skills but on students' logical thinking. The objective also recognizes the social domain of ICT as critical: ICT is a vehicle for developing ideological and moral education (VMOET, 2008), yet there are no discussions about these sociocultural implications.

The objectives of ICT education in Australian documents are different. They reflect a concern to develop positive attitudes towards ICT, as well as the development of knowledge and skills and information technology processes, expressed in terms of three major objectives: to appreciate ICT as an essential and relevant part of life; to develop students' ability to work with ICT; and to advance students' knowledge, skills and understanding. The Australian priority is the process of learning and application, with no narrow moral or ideological political objectives. As well, the ICT Stage 6 mention developing specific communication and language skills requested in ICT learning and teaching, aspects not mentioned in the current Vietnamese ICT curriculum. 


\section{The Nature of the ICT Curriculum in Vietnam and Australia}

The ICT curricula in Australia and Vietnam have many similar approaches, as well as with the curricula of many other countries. Both countries stress the importance of mastering ICT knowledge and skills. However, deeper analysis of the scope and sequence of content reveals distinct differences in curricular expectations. In Australia's Federal system, there are specific rules for the organization of school education for each State. In this paper, the State of New South Wales (NSW) is taken to represent Australian education. In contrast, in Vietnam, the educational system is uniquely synchronized between each local.

\section{Social and ethical issues}

As expected, the ICT curricula approach social and ethical issues in both countries. One of the major differences is the way social and ethical issues are discussed in the ICT curriculum in both countries. To bring together details of "social and ethical" or "informatics and social" issues referred to earlier, Table 1 shows major differences between the NSW and Vietnamese secondary school ICT curricula.

The Table 1 shows that the Vietnamese curriculum includes fewer details regarding social and ethical aspects than the NSW curriculum. Social and ethical issues (or informatics and social issues) are important for students in learning ICT procedures and actually using ICT applications. UNESCO (2004) asserts that connecting ICT with teaching social and ethical issues helps students understand the social, economic, and ethical issues related to the use of information technology. It explains the past and present states of computing development and projects trends. The NSW Board of Studies (2010) requires students to be introduced to software widely used in society, to consider how the software originated, and to reflect on issues arising from the course of development of the technology. Social and ethical content accounts for 10 per cent in Year 11 and is still maintained at 7 per cent in HSC examination Year 12.

By contrast, social and ethical content are not emphasized in Vietnamese ICT education. As Table 1 shows, ethical issues are not a specific part of the curriculum. Social and ethical issues are taught only in Year 10, in a small section amounting to 20 lines (Informatics Year 10, 2010). This observation may be related to the high rate of pirated software used in Vietnam. According to the Business Software Alliance (BSA) (2013), 81 per cent of software used in Vietnam was unlicensed compared to the Australian rate of 21 per cent. Therefore, on this criterion, this table shows that the Vietnamese and Australian ICT curricula have few similarities. 
Table 1: Comparisons of social and ethical issues of ICT curricula

\begin{tabular}{|c|c|c|}
\hline Content & NSW & Vietnam \\
\hline Legal issues & $\begin{array}{ll}\text { - } & \text { Copyright and/or licensing } \\
\text { - } & \text { Piracy } \\
\text { - } & \text { Intellectual property } \\
\text { - } & \text { Security and protection } \\
\text { (including viruses) }\end{array}$ & $\begin{array}{l}\text { Cultural and social } \\
\text { legislation on } \\
\text { computerisation. }\end{array}$ \\
\hline Ethical issues & $\begin{array}{l}\text { - Code of practice and con- } \\
\text { duct } \\
\text { - Privacy and Security } \\
\text { - Inappropriate use including } \\
\text { hacking } \\
\text { - Data accuracy, validity, } \\
\text { and bias }\end{array}$ & $\begin{array}{l}\text { (Not included in Viet- } \\
\text { namese curriculum) }\end{array}$ \\
\hline Social issues & $\begin{array}{l}\text { - Changing nature of work } \\
\text { and enterprise } \\
\text { - Equity, access and control } \\
\text { for all users with respect to } \\
\text { gender, disability, and cul- } \\
\text { ture } \\
\text { - Industrial issues }\end{array}$ & $\begin{array}{l}\text { - Impact of Informatics } \\
\text { on the development of } \\
\text { society } \\
\text { - } \quad \text { Social computerization } \\
\text { - No aspects about di- } \\
\text { verse learners } \\
\text { - } \quad \text { No details about equity } \\
\text { and access }\end{array}$ \\
\hline $\begin{array}{l}\text { Industrial } \\
\text { issues }\end{array}$ & $\begin{array}{l}\text { - Rights and responsibilities } \\
\text { of users of ICT } \\
\text { - Ergonomic principles and } \\
\text { industry standards }\end{array}$ & 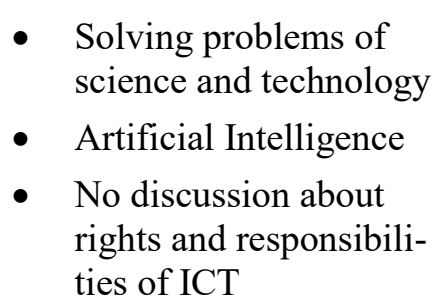 \\
\hline
\end{tabular}

\section{Hardware}

In both countries, the content curricula linked with hardware have many similarities, but there are some differences that show the degree and focus on explaining the hardware components. More details are presented below. 
Table 2: Comparisons of hardware topics of ICT curriculum

\begin{tabular}{|c|c|c|}
\hline Content & NSW & Vietnam \\
\hline $\begin{array}{l}\text { Hardware compo- } \\
\text { nents and functions }\end{array}$ & $\begin{array}{l}\text { 1) Motherboard } \\
\text { 2) Central processing unit } \\
\text { (CPU) } \\
\text { 3) Coprocessor chips } \\
\text { 4) Memory: random access } \\
\text { memory (RAM), read- } \\
\text { only memory (ROM) } \\
\text { 5) Hard disk } \\
\text { 6) Controller cards } \\
\text { 7) Graphics adapter cards } \\
\text { 8) Power supply } \\
\text { 9) Expansion slots } \\
\text { 10) Bus lines } \\
\text { 11) Input/output ports } \\
\text { 12) Display } \\
\text { 13) Cameras } \\
\text { 14) Digital watches } \\
\text { 15) Monitoring devices }\end{array}$ & $\begin{array}{l}\text { 1) Central processing unit } \\
\text { (CPU) } \\
\text { 2) Main memory: ROM } \\
\text { (read-only memory); } \\
\text { RAM (random access } \\
\text { memory) } \\
\text { 3) Secondary Memory: Hard } \\
\text { disk, Floppy disk, CD disk, } \\
\text { and USB } \\
\text { 4) Input devices: Keyboard; } \\
\text { Mouse; Scanner; } \\
\text { Webcam } \\
\text { 5) Output Devices: Monitor, } \\
\text { Printer, Projector, Speak- } \\
\text { er and Headphone, and } \\
\text { Modem }\end{array}$ \\
\hline Hardware solutions & Developing hardware solutions & $\begin{array}{l}\text { Not included in Vietnamese cur- } \\
\text { riculum }\end{array}$ \\
\hline
\end{tabular}

Table 2 displays essential similarities in hardware education. The Australian lesson content however is more sophisticated. The Australian curriculum (Australian Curriculum, Assessment and Reporting Authority [ACARA], 2012) includes training content that covers hardware system and function components; the way in which a variety of input devices, output devices, storage devices and CPU components achieve their purpose; and current developments in computer hardware and trends. The Vietnamese textbook (Year 10), on the other hand, provides only brief, sketchy descriptions of major hardware concepts, so that when students' study relates to hardware, they experience difficulty in understanding. Likewise, it can be noticed that Vietnamese curriculum describes some outdated components such as floppy disks and CDs. Overall, the table shows that in NSW the curriculum presents more content about hardware solutions, while in Vietnam, this content is treated very frugally.

\section{Software}

While the hardware section similarly approached the main aspects of the hardware in both countries, it was found that the software and the role of the software in ICT curriculum differed markedly. For instance, with more than 50 per cent of the total time for ICT instruction, the role of programming was heavily emphasized in Vietnam to the detriment of applying ICT software in real life. In contrast, the role of programming was minor in the Australian ICT curriculum, as there was less than 20 percent of the total time for instruction. Furthermore, the use of databases such as Access were heavily documented and offered effective time for mastering in the Vietnamese curriculum, while in the Australian curriculum it was barely mentioned. 
Table 3: Comparisons of software topics of ICT curriculum

\begin{tabular}{|c|c|c|}
\hline Content & NSW & Vietnam \\
\hline $\begin{array}{l}\text { Concepts and } \\
\text { Issues }\end{array}$ & $\begin{array}{l}\text { 1) Evolution of software applica- } \\
\text { tions } \\
\text { 2) Intellectual property } \\
\text { 3) Social context of software de- } \\
\text { sign }\end{array}$ & $\begin{array}{l}\text { 1) The concept of software } \\
\text { 2) Distinguishing between software } \\
\text { and system software; } \\
\text { 3) Operating system; } \\
\text { 4) File and file management; } \\
\text { 5) Communicating with the operat- } \\
\text { ing system; file processing; }\end{array}$ \\
\hline $\begin{array}{l}\text { Introduction } \\
\text { to Software } \\
\text { Development }\end{array}$ & $\begin{array}{l}\text { Learning a programming lan- } \\
\text { guage }(\mathrm{C} / \mathrm{C}++, \text { Java, Visual } \\
\text { Basic, Python) } \\
\text { 1) Defining and understanding the } \\
\text { problem; planning and design- } \\
\text { ing software solutions; } \\
\text { 2) Implementing software solu- } \\
\text { tions; } \\
\text { 3) Testing and evaluating soft- } \\
\text { ware solutions; } \\
\text { 4) Maintaining software solutions }\end{array}$ & $\begin{array}{l}\text { Learning a programming lan- } \\
\text { guage (Pascal, or } \mathrm{C} / \mathrm{C}++) \\
\text { 1) Text editor; } \\
\text { 2) Some concepts of programming } \\
\text { and programming languages; } \\
\text { 3) Simple program; } \\
\text { 4) Branching and loop structure; } \\
\text { 5) Structured data types; } \\
\text { 6) Files and file operations; } \\
\text { 7) Subprograms and structured pro- } \\
\text { gramming } \\
\text { 8) Implementing algorithms }\end{array}$ \\
\hline $\begin{array}{l}\text { Developing } \\
\text { Software } \\
\text { Solutions }\end{array}$ & $\begin{array}{l}\text { 1) Project management } \\
\text { 2) Documenting software solu- } \\
\text { tions } \\
\text { 3) Developing software solutions } \\
\text { 4) Social and ethical issues relat- } \\
\text { ed to software solutions }\end{array}$ & $\begin{array}{l}\text { 1) The concept of a database sys- } \\
\text { tem; } \\
\text { 2) System Administrator database } \\
\text { Microsoft Access; } \\
\text { 3) System database relations }\end{array}$ \\
\hline $\begin{array}{l}\text { Development } \\
\text { \& Impact of } \\
\text { Software } \\
\text { Solutions }\end{array}$ & $\begin{array}{l}\text { 1) Social and ethical issues } \\
\text { 2) Application of software devel- } \\
\text { opment approaches }\end{array}$ & $\begin{array}{l}\text { Not included in the Vietnamese cur- } \\
\text { riculum }\end{array}$ \\
\hline $\begin{array}{l}\text { Software } \\
\text { Development } \\
\text { Cycle }\end{array}$ & $\begin{array}{l}\text { 1) Defining and understanding the } \\
\text { problem } \\
\text { 2) Planning and designing soft- } \\
\text { ware solutions } \\
\text { 3) Implementation of software so- } \\
\text { lution } \\
\text { 4) Testing and evaluating of } \\
\text { software solutions } \\
\text { 5) Maintaining software solutions }\end{array}$ & $\begin{array}{l}\text { Knowledge and security database } \\
\text { systems }\end{array}$ \\
\hline
\end{tabular}


Table 3 illustrates major differences in curriculum software content between the two educational systems. NSW software content provides much more detailed information on Software Development, Software Solutions, and the Software Development Cycle. The Vietnamese ICT curriculum allocates a greater amount of time for learning programming. It aims to help students do programming and, unlike the Australian curriculum, teaches basic algorithms with a choice of teaching from one of the outdated list of programming languages. As such, we noticed a difference of programming languages accepted for ICT curricula. While in Australia there are a variety of languages such as $\mathrm{C} / \mathrm{C}++$, Java, Visual Basic, or Python, in Vietnam only Pascal or $\mathrm{C}++$ languages are accepted. Likewise, as Ho et al. (2010) would confirm, the Vietnamese curriculum does not provide knowledge and understanding of legal, social, and ethical issues and their effect on software design and development, and it does not focus on skills in teamwork and communication associated with the design and development of software solutions, as in NSW.

\section{Network and Internet}

In Australia, Network and Internet content is taught in Years 7-10 as two optional sections of curriculum, out of a total of eight. In Vietnam, students study only some basic concepts of network and Internet from one chapter of Year 10's textbook over a total of 12 periods: six periods of theory; four exercises/practical periods; and two exercises (Knowledge and Skills Standards Textbook for Year 10, 2010).

In Table 4, it can be noticed that the NSW curriculum is offering far more details about Internet and networking than the Vietnamese curriculum. For instance, it offers the possibility to discuss more about creating, implementing features on websites, and adequate access controls. Overall, we found that the content of the networks and internet is treated very basically in Vietnam, while the Australian offers more opportunities to learn a variety of concepts.

Table 4: Comparisons of network and Internet topics of ICT curriculum

\begin{tabular}{|l|l|l|}
\hline Content & NSW & Vietnam \\
\hline \multirow{5}{*}{ Internet } & 1) Historical perspective of the & 1) What is the Internet? \\
& \multicolumn{1}{|l}{ internet } & 2) Types of Protocols \\
& 2) Uses of the Internet & 3) Organizing and accessing in- \\
& 3) Internet software & 4) Finding Information on the In- \\
& 4) Types of protocols & ternet \\
& 5) World Wide Web (www) & 5) E-mail \\
& 6) fontrol of access to web in- & 6) The issue of information securi- \\
& 7) Website development & 7) Uses of Internet \\
& & 8) Explorer
\end{tabular}




\begin{tabular}{|c|c|c|}
\hline Content & NSW & Vietnam \\
\hline $\begin{array}{l}\text { Networking } \\
\text { Systems }\end{array}$ & $\begin{array}{l}\text { 1) A communications network } \\
\text { 2) Data transmission modes } \\
\text { 3) Data transmission rates } \\
\text { 4) Data transmission media } \\
\text { 5) Types of networks } \\
\text { 6) Client server and peer-peer } \\
\text { networks } \\
\text { 7) Components of networks } \\
\text { 8) Security of information } \\
\text { 9) Network topologies } \\
\text { 10) Network operating systems } \\
\text { 11) Factors influencing media } \\
\text { transmission } \\
\text { 12) Project development }\end{array}$ & $\begin{array}{l}\text { 1) The concept of computer net- } \\
\text { work } \\
\text { 2) Communication protocols of } \\
\text { computer networks } \\
\text { 3) Classification of computer net- } \\
\text { works } \\
\text { 4) Global Information Network } \\
\text { 5) The network model }\end{array}$ \\
\hline
\end{tabular}

\section{Developing a software solution package}

The NSW curriculum focuses on designing and developing a software solution to a complex problem. It is suggested that students learn how to design software and how to document the progress of their project as well as various tools such as email messages, spreadsheets, blogs, and handwritten dated entries. With each entry, the ICT curriculum requires students to describe time and date, tasks achieved, difficulties and solutions, ideas and thoughts, reflection on progress, and reference to resources used. In contrast, the curriculum in Vietnam cannot accommodate all this in its secondary schools due to the limited time for ICT teaching and learning, and the ICT curriculum is not updated frequently (from 2008 to present, VMOET has only been revised one time, in 2011).

\section{Constructivism in ICT Curriculum}

Another major trend in contemporary ICT education is based on the concept that students are actively involved in the construction of ICT knowledge. Constructivist theory in ICT learning suggests that learners personally negotiate meaning by creating different mental representations of ICT knowledge. Australian ICT documents such as Statements of Learning for ICT (2006) emphasize the knowledge, skills, understandings, and capacities that students in Australia should learn and develop in ICT. By comparison, in Vietnam, The Vietnam Education Law (2005) requires that methods of teaching promote the activeness, consciousness, initiative, and creativeness of students. The constructivist approaches to learning and teaching, in fact, confront the traditional educational conducive to rule-based learning that emphasizes specific lessons in very prescriptive ways. This might be because the approach to constructivism is new and the national infrastructure supporting has not been updated with the new requirements. By including recent ICT processes in the curriculum objectives, the newly published version in Vietnam adopts, to some extent, a constructivist view of ICT teaching and learning addressing the link between and interests in ICT education activities.

In Australia, the ICT curriculum developers have essentially adopted some constructivist views of ICT in education that recognizes its capacity to handle various aspects of reality as learners con- 
struct their own knowledge. The Australian documents emphasize the practical value of ICT in social science, medicine, economics, commerce, engineering, and art. Apart from the information technology aspect, there is clear emphasis on ICT as a means of communication. It is a fair interpretation of the rationale here to say that the Australian ICT curriculum is based on a philosophy of pragmatism and constructivism. However, there is a high emphasis on standardized national assessments, which induce test standardization and might make many educators careers dependent on these national results. As a result, educators are cautious on using this philosophy in secondary schools.

As a general statement, the Australian curriculum focuses on developing processes and practical utilization of ICT knowledge, skills, and creativity, while the Vietnamese curriculum focuses on solving simple problems through few choices of programming languages. The Australian curriculum adopts a constructivist approach to ICT learning diminished by the pressure on national standard tests, while the Vietnamese curriculum attempts to implement constructivist approaches but it still have a traditional approach to ICT education based on presentation of a fixed body of knowledge.

\section{Summary}

The four major strands - social and ethical issues, hardware, software, and internet and network were contained in both Australian and Vietnamese ICT curricula. However, there were quite a few differences in content and emphasis that were described here. We can say that Australian curriculum developers have achieved a balance of content across the four strands identified in the curriculum. However, the aspects of designing and programming software were minimally covered. In contrast, the Vietnamese curriculum developers place a heavy emphasis on the software programming strand, but overall they fail to balance the four dimensions of the ICT curricula. As for the fifth strand related to strategies of development of software packages, this is found only in Australia.

As a general statement, the Australian curriculum focuses on developing processes and practical utilization of ICT knowledge, skills, and creativity, while the Vietnamese curriculum focuses on solving simple problems through some programming languages. Both countries have limited approach in adopting constructivism. The Australian curriculum adoption of constructivist in ICT curriculum is limited by pressure on highly standardized tests, while the Vietnamese curriculum still remains captive to a traditional approach to ICT education based on transmission educational models. It was noticed that the use of ICT in real life was very differently emphasized in the two national curricula. For instance, the Australian curriculum encourages the use of a great variety of software in various areas. In contrast, the Vietnamese curriculum has few ICT applications provided for the practical use or to be used in other disciplines except ICT curriculum.

\section{Assessment Methods in Australia and Vietnam}

\section{The Nature and Purpose of Assessment}

The Australian curriculum framework embodies assessment as an integral part of the learning process, aimed at optimizing the learning process. For instance, in Stage 6, assessment is described as the process of gathering evidence of and making judgment about students' needs, strengths, abilities, and achievement. Information gained through assessment provides feedback to students and teachers, leading to more effective learner-centered programs and ultimately improvement in student learning. The assessment in Stage 6 gathers information on student development and achievement, helps to plan further learning experiences, and gives teachers a starting point to evaluate the teaching program and also target particular learner groups. 
In Vietnam, curriculum documents base ICT education assessment on teaching objectives and basic syllabus requirements and show very ambitious goals. Student mastery of basic ICT knowledge and ability are assessed. The teacher should also improve assessment methods in order to enhance student learning, however the teaching resources are coming exclusively from outdated textbooks. The standards see the purpose of assessment being to enhance students' all-round moral, intellectual, and physical education development. However, there are no direct indications that could describe how these aspects can be effectively improved. In addition, the syllabus also envisages improved methods of assessment as a means of encouraging students to study harder. Unfortunately, it does not mention concrete paths on catering to students' needs and diversity. Similar with what Pham (2014) found, the analyzed documents acknowledge that there are not enough students who do well in ICT classes.

In both countries, assessment policies are closely linked with teaching and learning, and the major purpose of assessment is to enhance student learning outcomes. Yet, the rationales for assessments are quite different. The Australian documents focus on flexible and positive feedback to teachers that comes out of assessment in relation to teaching methods, while the Vietnamese documents focus on using assessment feedback to promote student self-motivation for improvement in their studies.

\section{Principles of Assessment}

Since 1991, the Australian Educational Council stipulated that assessments need to reflect all of the goals of the school ICT curriculum and be demonstrably fair, valid, and reliable. This perspective was kept in the following decades (Morgan, Sheard, Butler, \& Weerasinghe, 2015). The Vietnamese syllabus approach is broadly similar: ICT assessment should be based on the teaching objectives and basic requirements of the syllabus, requirements that often become very rigid. Not only should students' mastery of basic ICT knowledge be assessed, but also their practical ICT ability. Thus, the operative principle of both education systems is to align assessment with stated syllabus/curriculum outcomes.

\section{Strategies for Assessment}

There are different sets of strategies in both countries for the development of assessment. Since 1991, the Australian National Statement (Australian Education Council, 1991) urges continued emphasis on useful, practical, and fair assessment strategies. The ICT Stage 6 recognises the need for students to demonstrate their learning through speaking, writing, drawing, and engaging in other activities, and so encourages diverse methods of testing, practical investigation, recording of observations accompanied by student explanation and work samples, and structured interviews along with student-teacher discussions. In addition, the role of self assessment is emphasized as a way to critically evaluate personal achievement.

The Vietnamese educational plan prescribes the form of assessment as open or closed book examinations or tests, or a practical test using practical manipulations. It recommends reporting the use of percentages or grades, with teacher comments as necessary. The syllabus encourages oral examinations and practical tasks in addition to written examinations. It emphasizes the role of daily classroom teaching and regular homework and, as well, the end of year examination. The standards suggest that thematic activities and essays, group activities, self-assessment, and daily observations be used by the teacher to make balanced assessments.

Documentary analysis of proposed assessment procedures shows a variety of strategies for ICT assessment. However, the Vietnamese system tends primarily to emphasize written examinations while NSW, as a representative of the Australian system as a whole, emphasizes a broader range 
of assessment strategies. Moreover, while Australian ICT curriculum allows and encourages team projects, Vietnames system allows individual assessments only.

\section{Other Assessment Issues}

In Vietnam, the curriculum guidelines document the use of both summative and formative assessment. With summative assessment, which is reckoned at the end of the course of study, student achievement is measured against the specified learning objectives of the syllabus. Thus, end of semester and school year end examinations as well as the final secondary school examination assess achievement. The ongoing process of formative assessment on the other hand, which enables feedback and guidance, is strongly oriented towards assisting students to improve their understanding and their performance (MacMath, Wallace, \& Chi, 2009). Another way of viewing the process is as a one-off formal semester assessment as opposed to informal assessments that will occur during teaching and learning activities.

In Australia, at both national and state level, several official documents such as secondary ICT outcomes and indicators provide common guidelines and examples to assist teachers, schools, and systems with the complex process of assessment. Recently, online assessments started to be implemented in schools. It is intended that an increasing number of local and national assessments to be moved online (Australian Government, 2013). The overall intention is to take models of appropriate assessment and make their requirements and methodologies explicit for the teachers who need to use them in practice.

\section{Final Discussions}

This study is a contribution to international comparative studies on ICT achievement in education, in theory and also in terms of practice. It has provided a tentative explanation for the ICT achievement gap between Vietnam and Australia. As far as practical work is concerned, the following summarizes its practical implications. As far as methodology is concerned, document analysis has been shown to be an effective method of exploring ICT curriculum and assessment practices. Vanderlinde, Dexter, and van Braak (2012) show that the school-based ICT practices reflected the policy intentions of the national ICT in education. Although it can be argued that these methods were time-consuming, they provided more in-depth analyses than would have been possible with a large-scale quantitative study.

This study has found that, despite being capable of building a national ICT infrastructure for schools, both countries have engaged in national strategies in ICT education in dissimilar and multifold ways. More exactly, in Australia, the government has made a major achievement in implementing ICT teaching and learning infrastructure at secondary schools. It was found that "DER provided the basic building blocks for better integration of technology into teaching and learning, but the uptake and commitment to the DER initiative was not universal. Results did not occur unless there was significant, planned and sustained school level engagement" (Australian Government, 2013, p. 20). In contrast, in Vietnam, while the Vietnamese government achieved an ICT infrastructure, this infrastructure is not conducive for learning and teaching. It is significant that the government has engaged in ICT planning but has not been able to report at least modest achievements in ICT teaching and learning in high schools. This study, therefore, recommends that the Vietnamese government issue annual reports regarding the progress of ICT teaching and learning in high schools and launch a comparison between urban and rural areas in Vietnam to enable the government to make suitable investments to ensure quality ICT teaching and learning in each area.

Australia and Vietnam both follow a global educational reform agenda. Their objectives, content, and suggestions for teaching, learning, and assessment of the subject of ICT are commonly held 
in many different ways. Both systems advocate an outcomes-based rationale, both tried to adopt a limited constructivist approach towards teaching and learning, and both encourage the alignment of assessment practices with teaching and learning. It should be said however that there are underlying differences between the rationales of each respective educational system, in particular in the Vietnamese tendency to assess a body of ICT knowledge as opposed to the Australian tendency to assess a growing capacity to apply ICT skills, though it must be accepted that there are differing systemic educational resources involved.

ICT policies from the two countries were found to be substantially different. While the Vietnamese ones are highly centralized and bureaucratic, the Australian policies are more realistic and pragmatic. While, according to VMOET, the present assignments are inclined to solicit more theoretical aspects of ICT, the Australian requests for ICT assessments are rather practical, oriented towards applying ICT for different types of applications, in order to produce different real-world outcomes. In addition, while the Australian schools started to implement online assessments and try to do major changes, this major task has not started yet in the Vietnamese schools.

Both countries have constructivist intents on ICT curriculum, but the constructivist aims are understood in different ways in the ICT curricula in Australia and Vietnam, and the educational outcomes are different. Discussing about constructivism, Wertsch (2010) notes Vygotsky's ideas have had great influence on the West in discussions of cognitive development. One of the main views is that individual thinking is shaped by social and historical context. Individual agency remains central, but interaction with society is fundamental. Also this model of cognitive development is designed between active agents and cultural tools, where cultural tools may be accessed in various ways. Vygotsky also argues that individual thinking has social origins. Discussing about ICT and constructivism, McDowell (2013) shows how in the design of ICT learning environments, learning activities need to accept difference and diversity in learners' interests, motivations, and goals. The social and political context of ICT in education is also important and, as such, we need to keep these discussions in broader cultural political contexts. In our analysis, we saw that, while social interactions with school and society are widely accepted, the Vietnamese curriculum is far too what we could call learner centered. Students are not engaged and are not encouraged to explore and understand their ICT ideas. Instead, they are often forced into rote learning and have a standard time allocated for each stage of learning.

We noticed that the nature and content of the ICT curriculum was regarded widely differently. While both countries accept the two facets of the ICT education (one oriented towards practical ICT applications and the other oriented towards the theoretical part of ICT and to software programming), the time allocation and the foci differ extremely. While Australian curriculum has an emphasis on the practical use of ICT applications and in applying them in all aspects of schooling and day-to-day life, the Vietnamese curriculum has an emphasis on software programming and theoretical aspects of ICT. This might be somehow understandable, as the Vietnamese government cannot afford to import ICT professionals from overseas and wants to prepare as many is possible programmers trained for creating future ICT jobs that are paid well beyond the national average salary (Pham, 2014), while Australia, despite offshoring many ICT jobs (Parliament of Australia, Department of Parliamentary Services, 2005), has a deficit of ICT specialists and has policies of adopting them from overseas (Pennington, 2012), as ICT jobs are on the General Skilled Migration (GSM) program, a program pursued by the Australian federal government to provide skilled workers with working visa or residence to work in Australia. 


\section{Conclusions}

The analyses of documents included in this study offer significant implications for curriculum and assessment policy-makers in both countries. For Vietnamese curriculum and assessment and for policy-makers in particular, it is suggested that the curriculum focus more on the process of students' learning. We found that creating an ICT infrastructure in schools does not translate immediately into creating adequate ICT arrangements conducive to learning and teaching. To guide teachers' in their practices, curriculum documents should include more specific ICT content and relevant aspects of using ICT in assessments. In terms of educational reform, it is recognized that major restriction in Vietnam are imposed by the traditional culture, and cultural factors must be considered when considering education reform. The success of any reform will ultimately depend on support from the teachers. In addition, in terms of bridging the gap between intended and implemented curricula, it is recommended that class sizes in Vietnam be reduced to ensure that teachers and students have more time to interact in the classroom.

Our study reveals the insufficient level of content knowledge and pedagogical opportunities of ICT teachers from both countries and the efforts of both governments to improve this situation. More opportunities need to be created as the DER final report recommended "while the DER could not have reasonably included more time for lesson planning as a component, there is a strong sense that this issue is important in capitalizing on ICT in the future" (Australian Government, 2013, p.40). To bridge the gap between intended and implemented content and policies in curricula and assessments, the Vietnamese government needs to analyze "in-depth experiences, local practices and research, acquiring experience the world, especially to countries with a development education and advanced curriculum to compile textbooks, and teaching materials to promote best practices and overcoming the limitations" (Vietnamese Assembly, 2014, p. 3).

Although we used only official documents in this paper, we noticed unexpected ways of reproducing day-to-day practices and sociocultural cultural aspects of the two countries in the documents and policies related to the ICT curriculum. These discussions and implications might reveal some possible suggestions on disseminating the present state of affairs and help us take concrete steps in improving present situation of ICT education. Providing ICT resources across the country remains a difficult problem for both countries (Australian Government, 2013; Vu, 2008), the professional development for ICT teachers has now a decisive role in assuring a successful implementation of ICT in education, economy and society. Therefore, more time and opportunities for professional development in ICT education needs to be given. As the Australian Government acknowledges, "without the time available to effectively learn and plan for the use of ICT in everyday teaching practices, teachers will struggle to improve their capability to operate effectively in the digital environment" (2013, p. 40).

In Vietnam, changes need to be designed and implemented with the ever-present caution that where personal values and beliefs are concerned, ideas and practices will not be able to be easily transplanted from one person to another or one culture to another (Bishop, 1996). Vietnamese cultural beliefs about achievement are based on traditional attitudes and values that play a part in the process of student learning. To improve learning and teaching ICT in Vietnamese secondary school, teachers should not wait for administrative and political factors to exclusively recommend them appropriate guidance from the Vietnamese government. We referred our findings and recommendations first with direct implications for the two countries involved in this study. However, as most comparative education studies do, there are some aspects that might cautiously refer to other countries that are problematic to generalize. While it is difficult to implement our findings in other countries, we believe that we provided in this article a rigorous comparative study that might give educators some insights on exploring the development of ICT curriculum, content, policies, and assessments in their own countries. 


\section{Acknowledgements}

A large part of this paper is included in Tran' (2015) doctoral thesis Exploring Quality Teaching of Information and Communication Technology in New South Wales and Yenbai High Schools: A Comparative Case Study. We would like to thank Allan White, Chewee Beng Lee, Dacheng Zhao, Michael Singh, Richard Johnson, Jinghe Han, and Paul Rooney, who helped us to improve our research focus and the quality of writing.

\section{References}

Adamson, B. (2012). International comparative studies in teaching and teacher education. Teaching and Teacher Education, 28(5), 641-648.

Ainley, J., Banks, D., \& Fleming, M. (2002). The influence of IT: Perspectives from five Australian schools. Journal of Computer Assisted Learning, 18(4), 395-404.

Australian Curriculum, Assessment and Reporting Authority (ACARA). (2012). The shape of the Australian curriculum: technologies. Retrieved October 62015 from: http://www.acara.edu.au/verve/ resources/Shape of the Australian_Curriculum _ Technologies __August 2012.pdf

Australian Education Council. (1991). K-12 technology curriculum map. Carlton: Curriculum Corporation.

Australian Government. (2013). DER mid-program review: Assessing progress of the DER and potential future directions. Final report. Retrieved August 252015 from https://docs.education.gov.au/system/files/doc/other/digital_education_revolution_program_review.pdf

Bertram, A., \& Waldrip, B. (2013). ICT for ICT's sake: Secondary teachers' views on technology as a tool for teaching and learning. Australian Educational Computing, 28(1). Retrieved August 26, 2015 from http://journal.acce.edu.au/index.php/AEC/article/viewFile/9/PDF

Bishop, R. (1996). Collaborative research stories: Whakawhanaungatanga. Palmerston North: Dunmore Press.

Bogdan, R., \& Biklen, S. (2007). Qualitative research for education: An introduction to theories and methods. Boston, MA: Person Education.

Business Software Alliance (BSA). (2013). The compliance gap: BSA global software survey. Retrieved August 21, 2015 from http://globalstudy.bsa.org/2013/

Convery, A. (2009). The pedagogy of the impressed: How teachers become victims of technological vision. Teachers and Teaching: Theory and Practice, 15(1), 25-41.

Cowen, R. (2009). Then and now: Unit ideas and comparative education. In R. Cowen \& A. M. Kazamias (Eds.), International handbook of comparative education (pp. 1277-1294). New York: Springer.

Crabtree, B., \& Miller, W. (1999). A template approach to text analysis: Developing and using codebooks. In B. Crabtree \& W. Miller (Eds.), Doing qualitative research (pp. 163-177.) Newbury Park, CA: Sage.

Cuban, L. (2009). Oversold and underused: Computers in the classroom. Massachutes: Harvard University Press.

Daly, J., Kellehear, A., \& Gliksman, M. (1997). The public health researcher: A methodological approach. Melbourne, Australia: Oxford University Press.

Denzin, N. K., \& Lincoln, Y. S. (2009). Qualitative research. Thousand Oaks, CA: Sage.

Farrell, G., Isaacs, S., Trucano, M., Hamdy, A., Hare, H., Tetang Tchinda, J., . . Fall, B. (2007). Survey of ICT in education in Africa, 53 Country Report: Volume 2. OAsis, COL's Publications Repository. 
Hadjerrouit, S. (2009). Didactics of ICT in secondary education: Conceptual issues and practical perspectives. Issues in Informing Science and Information Technology, 6, 153-178. Retrieved from http://iisit.org/Vol6/IISITv6p153-178Hadjerrouit605.pdf

Hans, N. (2013). Comparative education: A study of educational factors and traditions (Vol 4). New York: Routledge.

Higgins, S. J. (2003). Does ICT improve learning and teaching in schools? BERA, British Educational Research Association. Retrieved August 242015 from https://www.bera.ac.uk/wpcontent/uploads/2014/01/ict-pur-mb-r-f-p-1aug03.pdf

Ho et al. (2010). The standard of knowledge and skills of the ICT curriculum at high schools. The Vietnam Education Publishing House. Hanoi, Vietnam.

Hruby, G. G. (2001). Sociological, postmodern, and new realism perspectives in social constructionism: Implications for literacy research. Reading Research Quarterly, 36(1), 48-62.

Husén, T. (1967). International study of achievement in mathematics, A comparison of twelve countries (Volume 1). Stockholm, Sweden: Alm- Qvist \& Wiksell.

Jerrim, J. (2015). Why do East Asian children perform so well in PISA? An investigation of Western-born children of East Asian descent. Oxford Review of Education, 41(3), 213-333.

Kalenda, J., \& Schwartzhoff, S. (2015). Cultural sociology: A new approach to the study of the history of education. Procedia-Social and Behavioral Sciences, 174, 3055-3062.

Kozma, R. B. (2003). Technology, innovation, and educational change: A global perspective. Eugene, OR: International Society for Information Technology in Education.

Kozma, R. B. (2008). Comparative analysis of policies for ICT in education. In J. Voogt \& G. Knezek (Eds.), International handbook of information technology in primary and secondary education (pp. 1083-1096). New York: Springer.

Kozma, R. B. (2011). ICT, education transformation, and economic development: An analysis of the US National Educational Technology Plan. E-Learning and Digital Media, 8(2), 106-120.

Leung, F. K. (2001). In search of an East Asian identity in mathematics education. Educational Studies in Mathematics, 47(1), 35-51.

Livingstone, S. (2004). Media literacy and the challenge of new information and communication technologies. The Communication Review, 7(1), 3-14.

Livingstone, S. (2012). Critical reflections on the benefits of ICT in education. Oxford Review of Education, 38(1), 9-24.

Mack, N., Woodsong, C., MacQueen, K. M., Guest, G., \& Namey, E. (2005). Qualitative research methods: A data collectors field guide. North Carolina: Family Health International.

Markauskaite, L. (2005). Notions of ICT literacy in Australian school education. Informatics in EducationAn International Journal, 4(2), 253-280.

Markauskaite, L. (2007). Exploring the structure of trainee teachers' ICT literacy: The main components of, and relationships between, general cognitive and technical capabilities. Educational Technology Research and Development, 55(6), 547-572.

Maxwell, J. A. (2012). A realist approach for qualitative research. New York: Sage.

McDowell, D. G. (2013). Classroom technology integration: A comparative study of participants and nonparticipants in the 21st century model classroom program. Unpublished doctoral dissertation, Western Carolina University.

MacMath, S., Wallace, J., \& Chi, X. (2009). Curriculum integration: Opportunities to maximize assessment as, of, and for learning. McGill Journal of Education/Revue des sciences de l'éducation de McGill, 44(3), 451-465. 
Miller, O., \& Akume, B. (2009). The challenges of effective application of ICT aided learning in office technology education. A paper presented at the 21 st annual national conference of association of business educators of Nigeria (ABEN) on the 13th-17th October, 2009 at Abia State Polytechnic Aba, Abia State.

Morgan, M., Sheard, J., Butler, M., \& Weerasinghe, K. F. S. A. (2015, January). Teaching in first-year ICT education in Australia: Research and practice. In Proceedings of the 17th Australasian Computing Education Conference (ACE 2015) (Vol. 27).

Mullis, I. V., Martin, M. O., Ruddock, G. J., O'Sullivan, C. Y., \& Preuschoff, C. (2009). TIMSS 2011 assessment frameworks. ERIC.

Nóvoa, A., \& Yariv-mashal, T. (2007). 20 comparative research in education. A mode of governance or a historical journey? In M Crossley, P Broadfoot, M Schweisfurth (eds.), Changing educational contexts, issues and identities: 40 years of comparative education. New York: Routledge.

NSW Board of Studies. (2010). Software design and technology stage 6 syllabus. Retrieved October 10 2015 from http://www.boardofstudies.nsw.edu.au/syllabus_hsc/pdf_doc/software-design-developmentst6-syll-from2011.pdf

Organisation for Economic Co-operation and Developmen (OECD). (2005). Annual report for 2005. OECD Forum Report. Retrieved 3 August 2011 from http://www.oecd.org/dataoecd/34/6/34711139.pdf

Parliament of Australia, Department of Parliamentary Services. (2005). Offshoring jobs: US and Australian debates. Retrieved August 24, 2015 from http://aphnew.aph.gov.au/binaries/library/pubs/rb/200405/05rb12.pdf

Peeraer, J., \& Tran, T. (2010). Integration of ICT in education in Vietnam: From policy to practice. Retrieved 15 October 2015 from http://www.vvob.be/vietnam/files/IntegrationofICTineducationinVietnamFrompolicytopractice EN.pdf

Pennington, S. (2012, July 6). Australia to import more IT workers: Despite layoffs, recruiters say there are gaps in the market. Sydney Morning Herald. Retrieved August 24, 2015 from http://www.smh.com.au/it-pro/business-it/australia-to-import-more-it-workers-20120705-21kh2.html

Pham, H (2014, December 18). Computer science in Vietnam: Counting down to the hour of code. Forbes. Retrieved August 24, 2015 from http://www.forbes.com/sites/techonomy/2014/12/18/4560/

Prestridge, S. (2012). The beliefs behind the teacher that influences their ICT practices. Computers \& Education, 58(1), 449-458.

Quellmalz, E. S., \& Kozma, R. (2003). Designing assessments of learning with technology. Assessment in Education: Principles, Policy \& Practice, 10(3), 389-407.

Rautopuro, J., Pöntinen, S. \& Kukkonen, J. (2006). Towards the information society--The case of Finnish teacher education. Informatics in Education, 5(2), 285-300.

Sansanwal, D. (2009). Use of ICT in teaching, learning and evaluation. Educational Technology Lecture Series, 4.

Scardamalia, M., \& Bereiter, C. (2014). Smart technology for self-organizing processes. Smart Learning Environments, 1(1), 1-13.

Sellar, S., \& Lingard, B. (2013). The OECD and global governance in education. Journal of Education Policy, 28(5), 710-725.

Stoilescu, D. (2005). Using computers and software in the classroom. In J. Herrington \& B. Hunter (Eds.), Proceedings of the World Conference on Educational Media and Technology June 2005 (pp. 25562561), Chesapeake, VA: AACE.

Stoilescu, D. (2009). Multimedia CSCL tools and methods from a knowledge building perspective. Acta Didactica Napocensia, 2(1), 127-136. 
Tedre, M. (2007). Know your discipline: Teaching the philosophy of computer science. Journal of Information Technology Education: Research, 6, 105-122. Retrieved from http://www.jite.org/documents/Vol6/JITEv6p105-122Tedre266.pdf

Tran, T. M. (2015). Exploring quality teaching of information and communication technology in New South Wales and Yenbai high hchools: A comparative case study. Unpublished Doctoral Dissertation: University of Western Sydney, Penrith, Australia.

Tyner, K. (2014). Literacy in a digital world: Teaching and learning in the age of information. Routledge.

Ubulom, W., Enyekit, E., \& Onuekwa, F. (2011). Analysis of ICT accessibility and utilization in teaching of business studies in secondary schools in Andoni local government area of Rivers State. Academic Research International, 1(3).

United Nations Educational, Scientific and Cultural Organizatio [UNESCO]. (2004). EFA global monitoring report 2005: Education for all - The quality imperative. Paris: UNESCO.

Vanderlinde, R., Dexter, S., \& van Braak, J. (2012). School-based ICT policy plans in primary education: Elements, typologies and underlying processes. British Journal of Educational Technology, 43(3), 505-519.

Vietnamese Assembly. (2014). Project to change new text books and curriculum in Vietnemese Education. Vietnamese Government.

Vietnam Ministry of Education and Training (VMOET). (2008). ' Báo cáo tại hội thảo:" Đào tạo nguồn nhân lự ICT và truyền thông theo nhu cầu xã hội ' [Training of human resources in ICT and communication needs of society]. Da Nang, Vietnam.

Vu, D. C. (2008). Developing informatics teachers staff in high school in the view of standardization and socialization. Teacher Training College-Hanoi National University.

Wertsch, J. V. (2010). Vygotsky and recent developments. In E. Baker, B. McGaw, \& P. Peterson (Eds), International encyclopedia of education (3rd ed.), (pp. 231-236). Oxford: Elsevier.

Willinsky, J. (2014). The new openness in educational research. In A. D. Reid, E. P. Hart, \& M.A. Peters. $A$ companion to research in education (pp. 575-582). Amsterdam, Netherlands: Springer.

Whitaker, R. (2007). Applying phenomenology and hermeneutics in IS design: A report on field experiences. Informing Science: International Journal of an Emerging Transdiscipline, 10, 63-96. Retrieved from http://www.inform.nu/Articles/Vol10/DblHelix063-096.pdf

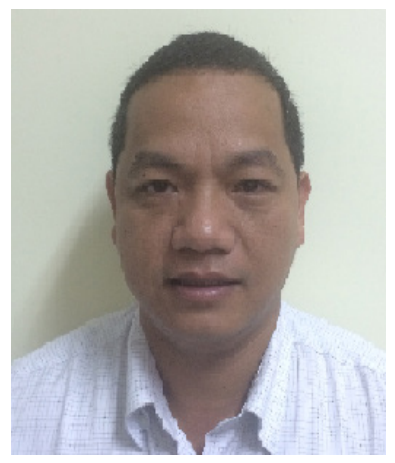

\section{Biographies}

Thang Manh Tran is a PhD student from the School of Education, Western Sydney University. His main research interests are: ICT curriculum and policies, teacher professional development, ICT teaching and learning, and mathematics education. He recently submitted his $\mathrm{PhD}$ thesis for examination. 


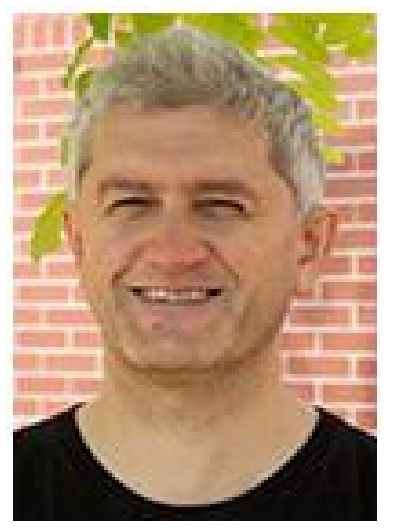

Dorian Stoilescu is lecturer in ICT and mathematics education at the School of Education, Western Sydney University. Some of his research topics are: ICT curriculum and policies, integrating ICT in mathematics curriculum and policies, integrating ICT in mathematics education, equity in ICT and mathematics education. 